\title{
Some of the Potential Affordances, Challenges and Limitations of Using GeoGebra in Mathematics Education
}

\author{
Yismaw Abera Wassie ${ }^{*}$, Gurju Awgichew Zergaw ${ }^{1}$ \\ ${ }^{1}$ Department of Mathematics, College of Science, Bahir Dar University, Bahir Dar, ETHIOPIA
}

Received 9 August 2018 - Revised 11 February 2019 - Accepted 28 February 2019

\begin{abstract}
In the modern era where technology usage is a tradition of the generation, integrating the teaching and learning with mediums that could catch up and satisfy pupils' interest is noteworthy. In line with this, the contributions of GeoGebra in the teaching-learning of mathematics: as a tool to foster students' interest and achievement, and as an environment to flourish different learning styles are explored in this study. Besides, the cautions to consider before implementing a GeoGebra integrated lesson with the challenges, limitations and areas of future development are indicated. Among these: the belief and technology fluency of users and the student class ratio are found to be among the challenges for effective integration of GeoGebra in mathematics lessons. The difficulty of some commands in the input bar especially for students and teachers with no prior programming experience are considered among the limitations of GeoGebra.
\end{abstract}

Keywords: GeoGebra, mathematics education, teaching resources, technology integration

\section{INTRODUCTION}

Nowadays, technology is influencing students' learning style preference from the very beginning of their schooling. Pupils prefer to see, to touch, and to comprehend what they learn. Scholars have also deduced that technological literacy is an essential skill of teaching with the power to motivate and create opportunities for students to comprehend, construct and explore new approaches to problem-solving (Bray \& Tangney, 2017; Lawless \& Pellegrino, 2007; Mainali \& Key, 2012). Thus, seamless integration of technology with learning has the advantage of enriching the processing power of students' mind to a new domain of knowledge representation through modelling, simulation, and visualization (Ahmad et al., 2010; Akcay, 2017; Guncaga \& Majherová, 2012; Kaput et al., 2008). Hence technologies are used as a medium to address conceptually rich topics, such as those in Mathematics, in an understandable way (Abramovich, 2013). These signifies, in present-days where technology usage is a tradition of the generation, assimilating the teaching and learning with mediums that could catch up and satisfy pupils' interest is of high value.

In response to the needs and for the benefits of learners, the web-based instructional tool, GeoGebra, has been proved to play significant role compared to Khan Academy, IXL, NCTM Illuminations, NLVM, (Lavicza, 2010; Little, 2008). The findings of Moeller and Reitzes (2011) and Velichova (2011) also underlined that integrating GeoGebra, with mathematics curricula can help to aid satisfaction of students, train students with skills essential for work and provide an active learning experience. GeoGebra is an interactive mathematics software created by Markus Hohenwarter in 2002 for teaching mathematics, mainly: algebra and geometry. From then on, GeoGebra has been developed by vibrant international communities in supporting the teaching-learning of simple to advanced courses in mathematics and related disciplines. The following features also make GeoGebra a preferred tool, to be considered in the teaching-learning process (Escuder \& Furner, 2011; Majerek, 2014; Velichova, 2011). GeoGebra:

- is a freely available, multi-platform, and composed of easy-to-handle tools.

(C) 2019 by the authors; licensee Modestum Ltd., UK. This article is an open access article distributed under the terms and conditions of the Creative Commons Attribution License (http://creativecommons.org/licenses/by/4.0/). \yismawa@bdu.edu.et (*Correspondence) $\square$ fevenjerry@gmail.com 


\section{Contribution of this paper to the literature}

- GeoGebra is a suitable teaching resource to improve students' engagement and achievement in selected topics of mathematics at upper secondary and tertiary educations.

- The potential of GeoGebra to assimilate different learning styles with possible challenges, gaps and areas of future improvement are presented.

- Limitations of GeoGebra 5.0. are indicated. Commands used in the input bar are not found to be userfriendly especially for those with no prior programming experience.

- $\quad$ support dynamic scenes.

- enables multiple representations of concepts.

- allows saving and exporting output files in multiple formats: ggb file, html file, $x m l$ files, and more.

- allows the insertion of images.

- works with LaTeX.

- has automated proof capabilities.

- is multilingual in its menus and its commands.

- enables for production of instructional materials including self-standing dynamic worksheets as interactive java applets that could be published on a website.

- has an active international community of users who provide teaching material and technical support.

This study would provide intuition to prospective students, teachers, and researchers in using GeoGebra for the teaching-learning of mathematics. Making use of our years of experience in using GeoGebra and results of literature, we create a research synthesis on contributions of GeoGebra for teaching mathematics and indicate possible gaps, challenges and areas of future development to the scholarly community. Questions like: how GeoGebra would contribute to the teaching-learning of mathematics? what are the challenges of integrating GeoGebra in the teaching-learning of mathematics? what are the limitations of GeoGebra? what precautions do mathematics teachers need to consider before integrating it? are also addressed in the study.

\section{METHODOLOGY}

In this study we used a qualitative approach. Peer-reviewed articles, conference papers and technical reports published in English through the period of 2007 to 2018 were considered from Mendeley library, Science Direct library, and the Education Resources Information Center (ERIC) databases by using the keywords GeoGebra and technology in math education. Forty articles from the Journal of Procedia-Social and Behavioral Sciences and eight articles from the journal of Computers \& Education were used in this study. The journals considered in the ERIC database include The International Journal for Technology in Mathematics Education, The International Journal of Mathematics Education in Science and Technology, EURASIA Journal of Mathematics, Science and Technology Education, The European Journal of Contemporary Education, Teaching Mathematics and its Applications, and Computers in the Schools. We also conduct a case to collect information about teachers' and students' view about GeoGebra.

Based on the survey of studies and the case, the information is categorized under the sub-topics: contributions of GeoGebra in teaching mathematics, GeoGebra's contribution to foster student interest and achievement and the challenges and limitations of integrating GeoGebra in the Teaching and learning.

\section{Contributions of GeoGebra in the Teaching-Learning of Mathematics}

GeoGebra's capability to integrate the algebraic and geometric concepts, makes it preferable in the discovery of mathematical truths and relations and hence to develop students' creative thinking skills (Lepmann \& Albre, 2008). For instance, visualizing the interactive 3D figures and surfaces in GeoGebra is more comprehensible than looking it on the static 2D piece of paper. GeoGebra has been used as a tool for automated proving and explanation of the Pythagoras Theorem (Kovács et al., 2016; Stando et al., 2012; Vargas, 2013). It is indicated that the approach helps to clarify the theorem and motivates students to be engaged with the lesson. The effectiveness of GeoGebra has been also evidenced in understanding geometric figures (Chan, 2013; Garber \& Picking, 2010; Laigo et al., 2016; Ljajko et al., 2010; Pereira et al., 2017), in solving linear optimization word problems (Molnár, 2016), and to describe eigenvalues and eigenvectors (José et al., 2017). The basic logic of symmetry (Akkaya et al., 2011), modelling of parametric curves (Velichova, 2011), Baravelle Spiral and their behaviours (Escuder \& Furner, 2011) and representations of complex functions (Gülseçen, 2012; Navetta, 2016) are also elaborated by using GeoGebra's tools. 


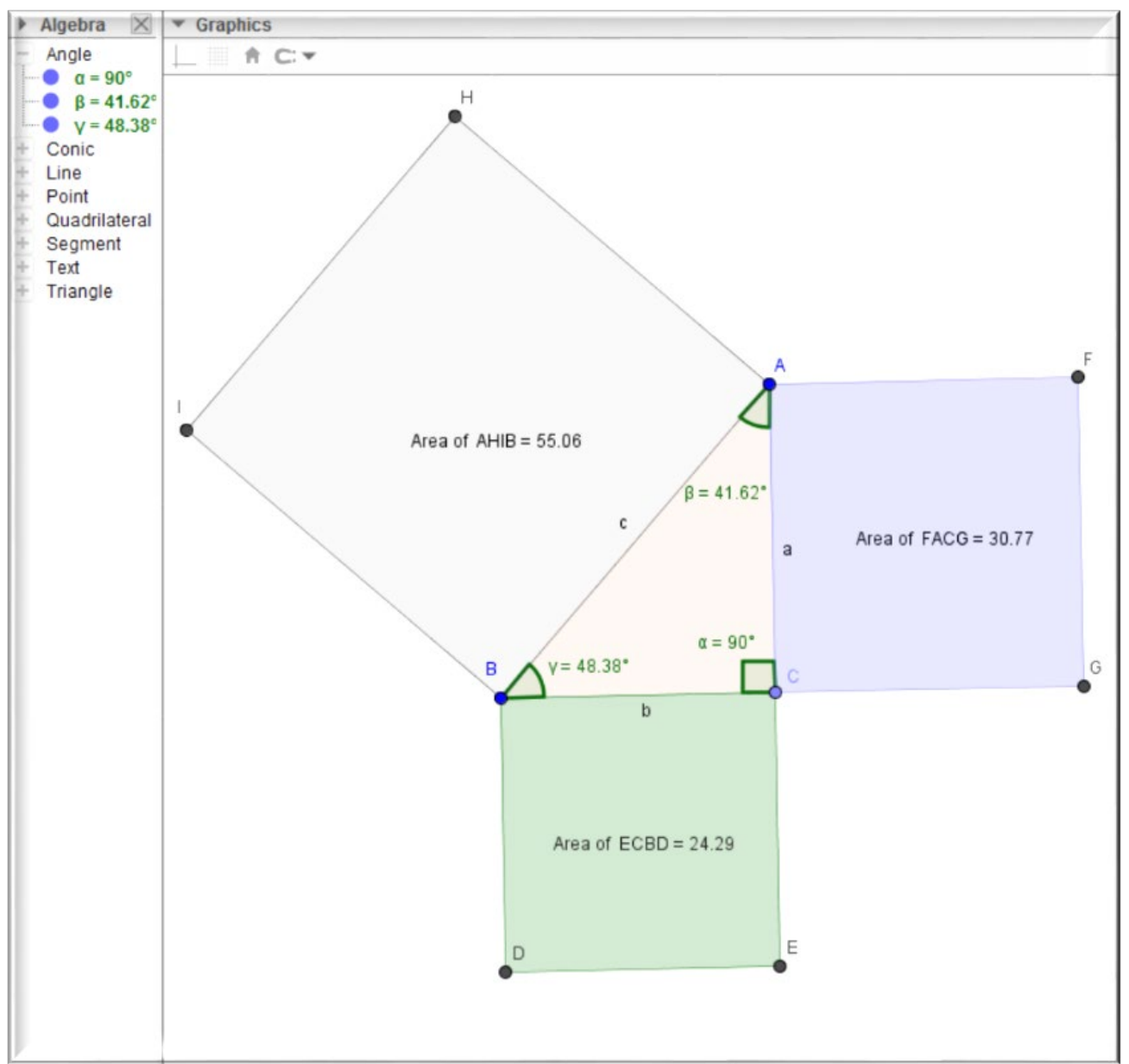

Figure 1. Pythagorean theorem explained using GeoGebra

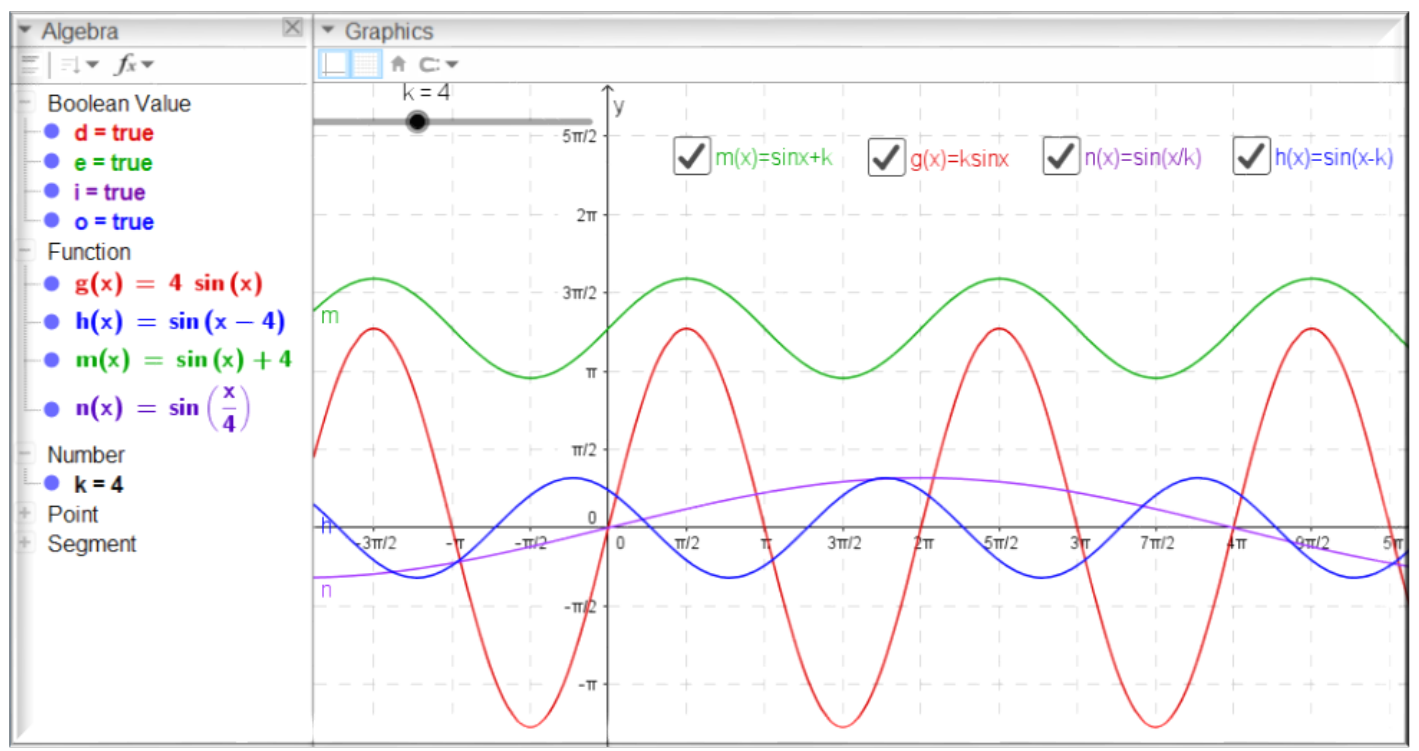

Figure 2. Effects of the parameter $\mathrm{k}$ on the graph of the functions $y=\sin x$

GeoGebra also plays a vital role in visualizing and understanding the effects of varying parameters (Figure 2) and the effects of rigid and non-rigid body transformations (Anabousy et al. 2014; Caglayan, 2011). It is also possible to characterize effects of degree and leading coefficient on the graph of higher degree polynomial functions, along with the domain and range, zeros and multiplicities of zeros, maximum and minimum values, intersection points, and intervals of monotonicity. 


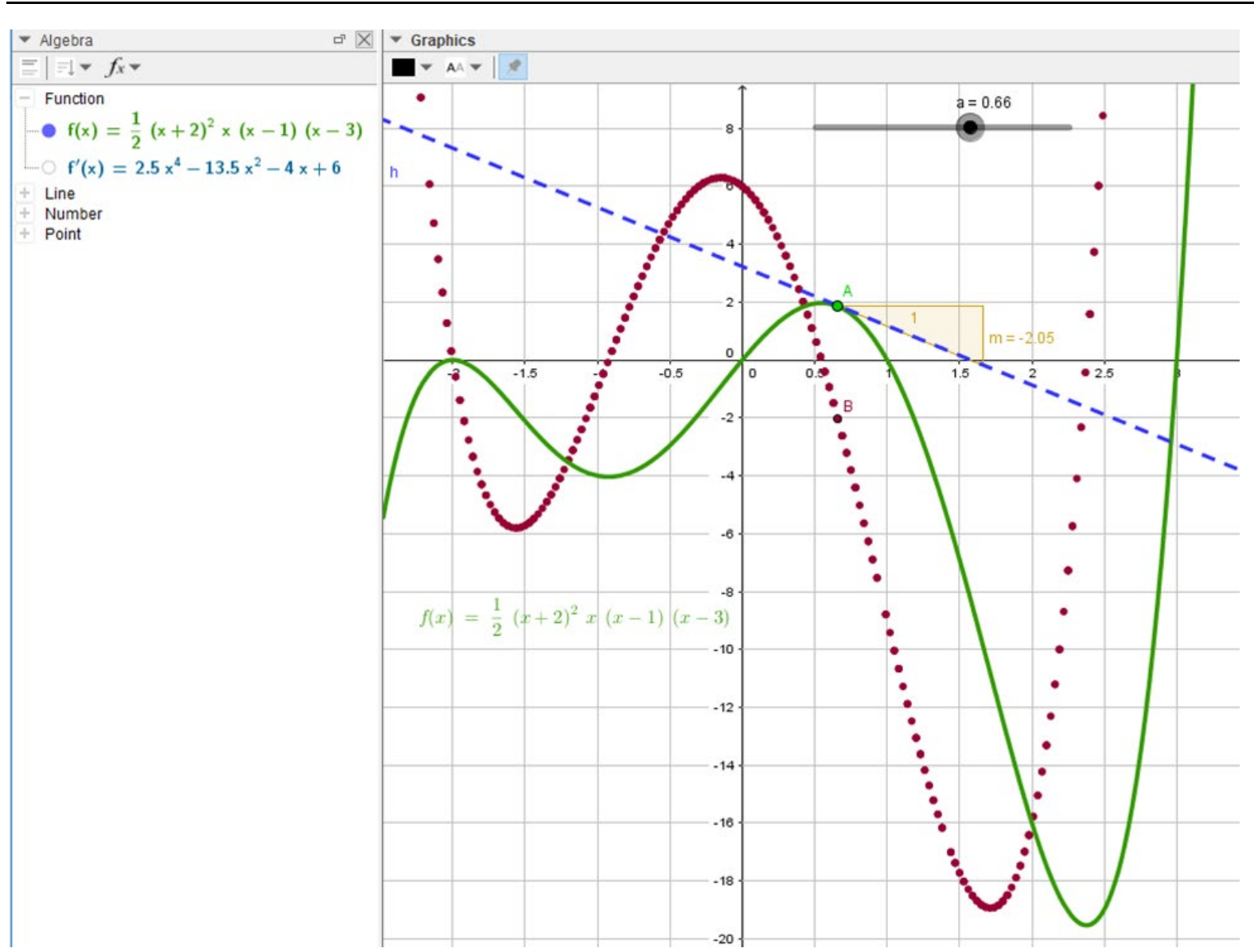

Figure 3. Derivatives of functions as a slope of a tangent line

The existence of the dynamic math software, GeoGebra, is an opportunity for researchers and teachers to augment the dynamic characteristics of many real-world phenomena. GeoGebra allows creating of teaching resources that could enhance the teaching-learning environment (Caligaris et al. 2015; Garber \& Picking, 2010; Little, 2011; Takači et al., 2015). On this regard, Dikovic (2009a, 2009b) used GeoGebra applets in teaching differential calculus, Akkaya et al. (2011) used GeoGebra for teaching symmetry, Liu et al. (2011) produced virtual manipulatives to teach angle concepts, Radović (2013) produced a virtual environment using GeoGebra for dealing with the surface area of solid figures, Pjanic and Liđan (2015) used applets to calculate areas of trapezoids. In addition, Caligaris et al. (2015) designed GeoGebra applets for showing the geometric interpretation of limits and the derivative of a function, and for explaining the relationship between the definite integral of a function and the area under a curve. In 2015, Martín-Caraballo and Tenorio-Villalón developed GeoGebra applets to work with numerical methods for nonlinear equations. Recently, Dvir and Tabach (2017) used GeoGebra to solve extrema problems by using a non-differential approach and José et al. (2017) used an applet of GeoGebra to calculate the moment of inertia, and to explain eigenvalues and eigenvectors from its geometrical perspective.

Figure 3 and Figure 4 show how GeoGebra could augment illustration of the concept of derivatives and integrals respectively. Figure 3, in particular, exemplifies the relationship between the graph of the function:

$$
f(x)=\frac{1}{2} x(x+2)^{2}(x-1)(x-3)
$$

and the graph of $f^{\prime}(x)$ in an interactive way. The green solid curve is the graph of $f(x)$ and the curve passing through the red dots is the graph of the function $f^{\prime}(x)$. This is one way of illustrating the derivative of a function as slope of a tangent line to the graph of the function. Similarly, the relation between the upper sum, lower sum, and the definite integral of a function can be explored using GeoGebra (Figure 4). 


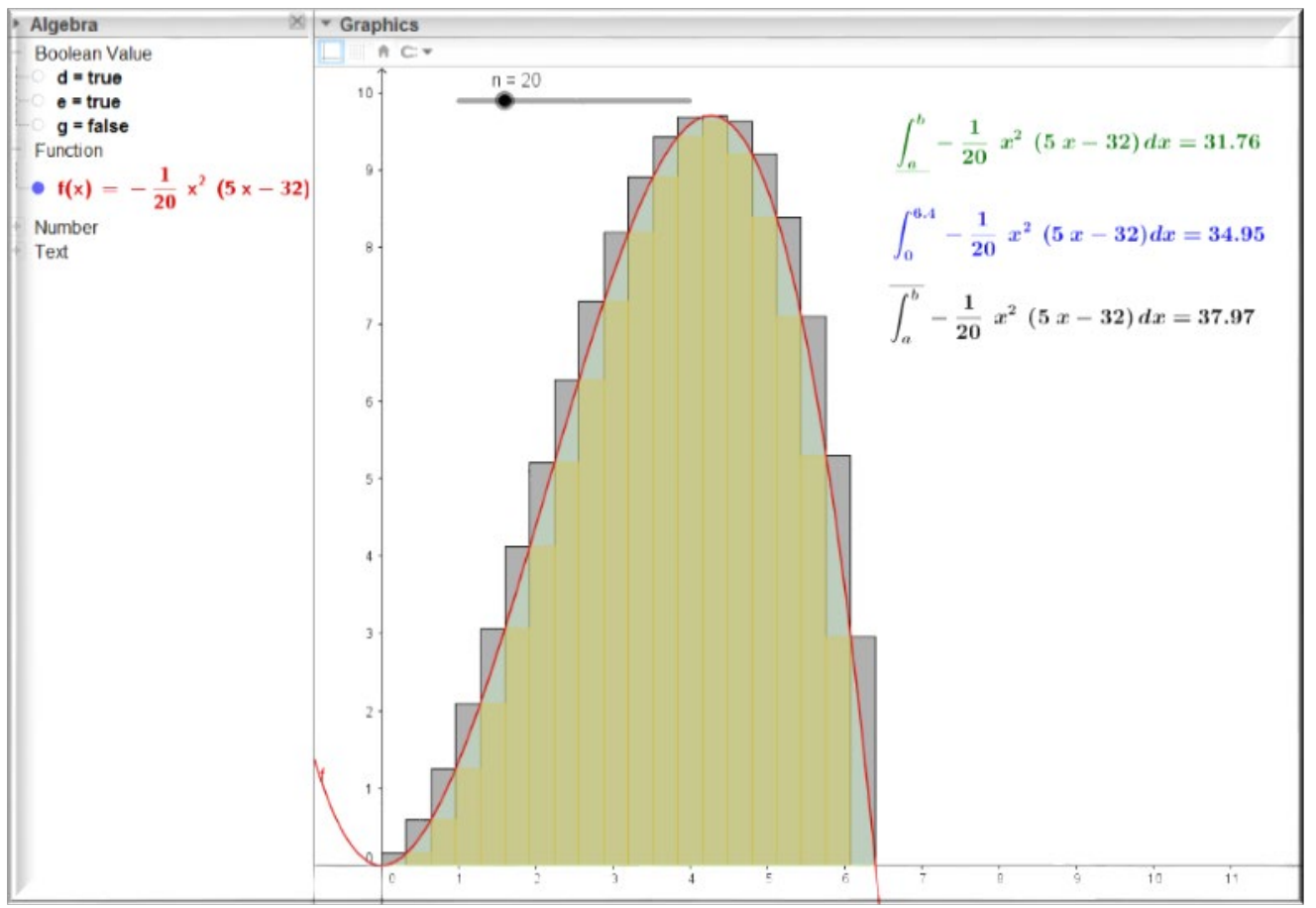

Figure 4. Lower and upper sums and definite integral demonstrated by GeoGebra

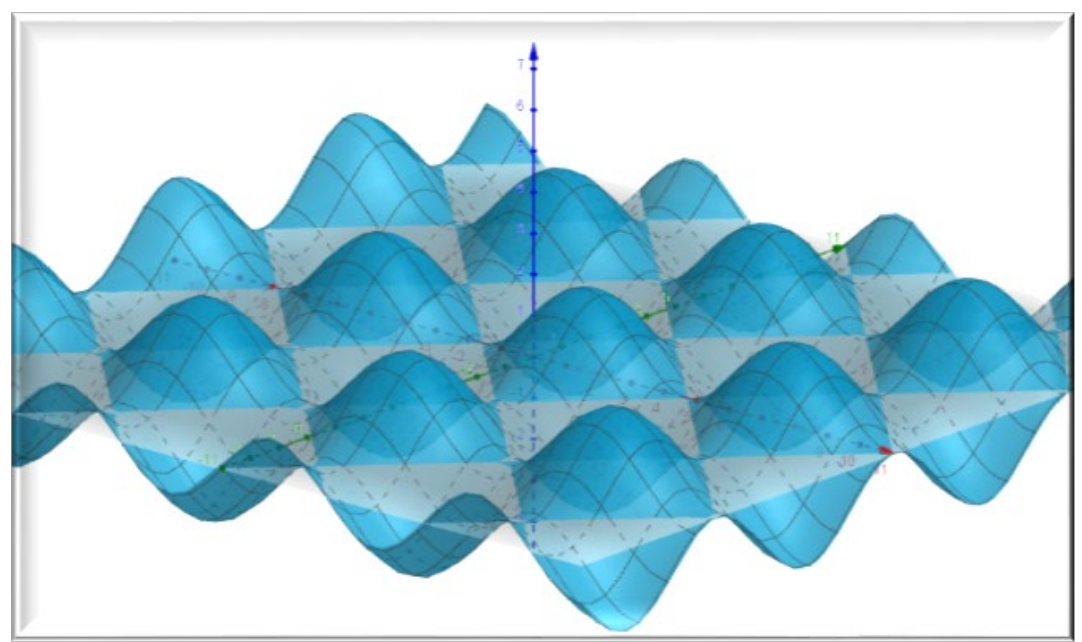

Figure 5. The surface of $f(x, y)=\sin x+\cos y$ sketched using GeoGebra 3D graphics window

GeoGebra has also been used in studying the properties of graphs of functions of several variables (Figure 5). Using the 3D graphics tool students can determine domains of functions of two variables, the intersection of solid figures and a plane, the contours, and so on.

Though using GeoGebra for studying functions of complex variables is still emerging, combining with domain colouring method, Breda and Santos (2016) has shown the potential of the tool in visualizing component graphs of functions of single complex variables (Figure 6). The parametric Bézier curves widely used in computer graphics and for animation purpose, can also be constructed with the help of the input bar and slider of GeoGebra as shown in Figure 7. 


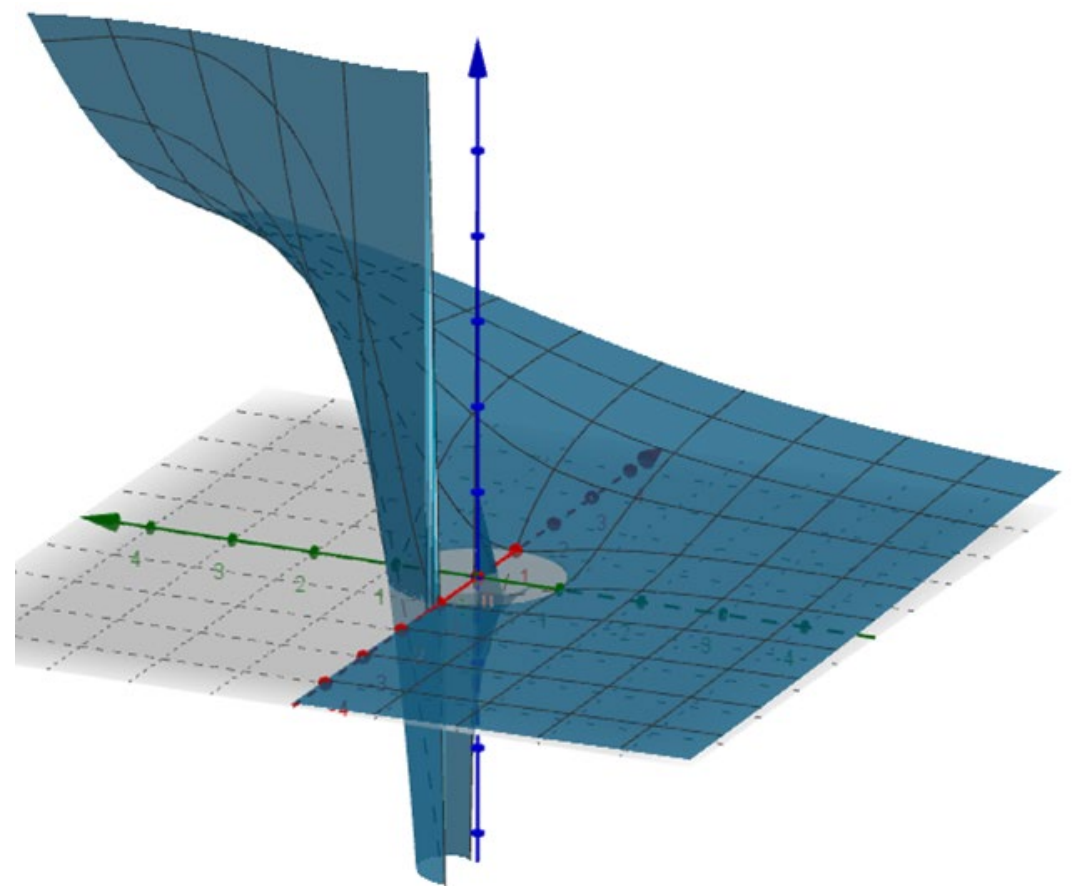

Figure 6. Graph of the imaginary part of the complex function $f(x, y)=(x-i y)^{i}$

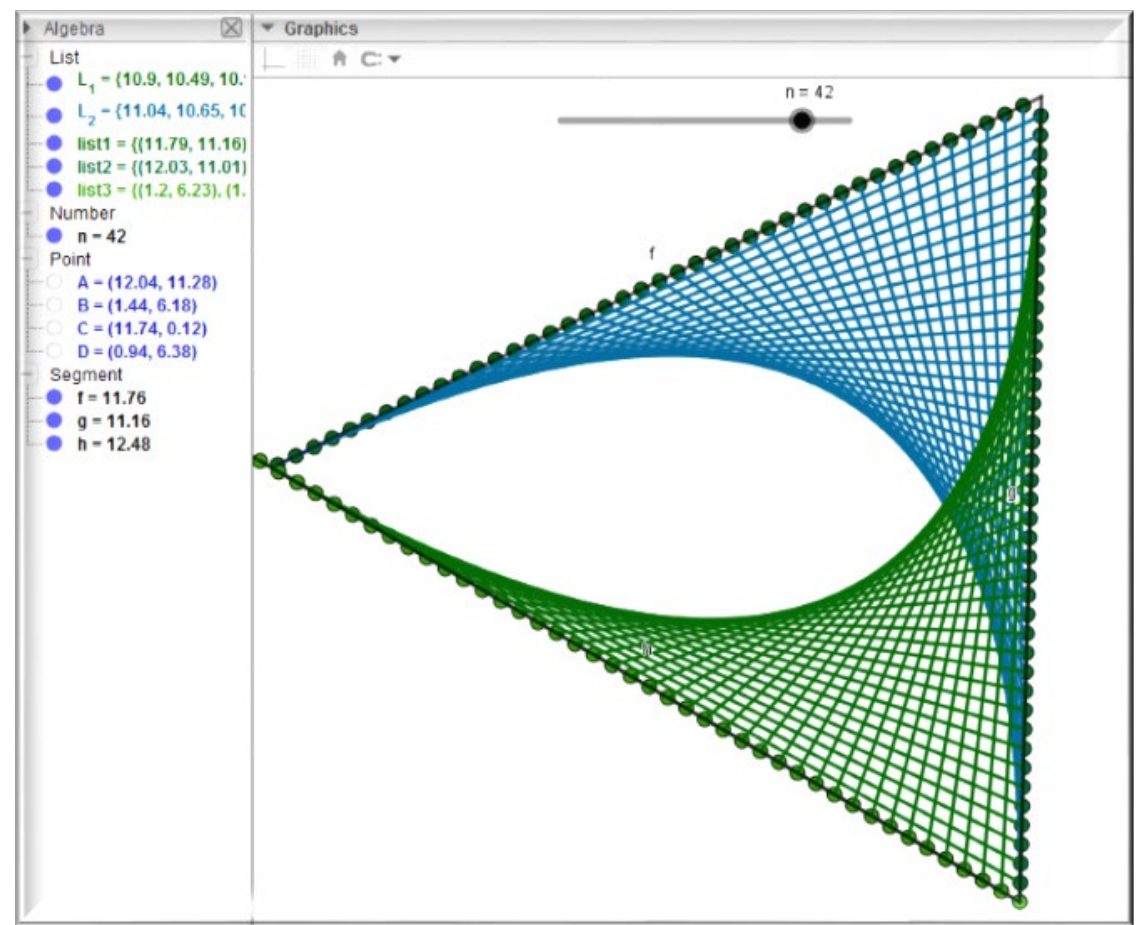

Figure 7. Bézier curves constructed with GeoGebra

\section{GeoGebra as a Tool to Foster Student Interest and Achievement}

GeoGebra supplemented lessons enhanced students' motivation (Liu et al., 2011; Reis, 2010; Reis \& Ozdemir, 2010; Vargas \& Gamboa, 2013) and their mathematical reasoning and problem solving skills (Acuña, 2014; Akanmu, 2016; Albaladejo et al., 2015; Granberg \& Olsson, 2015; Muzdalipah \& Yulianto, 2015). Particularly, lessons on coordinate geometry (Khalil et al., 2018; Saha et al., 2010), on trigonometry (Rahman \& Puteh, 2017; Zengin et al., 2012), in examining functions and their graphs (Takači et al., 2015), on statistics (Arbain \& Shukor, 2015; Emaikwu et al., 2015), in understanding theorems related to circles (Bhagat \& Chang, 2015; Praveen \& Leong, 2013), fractions 


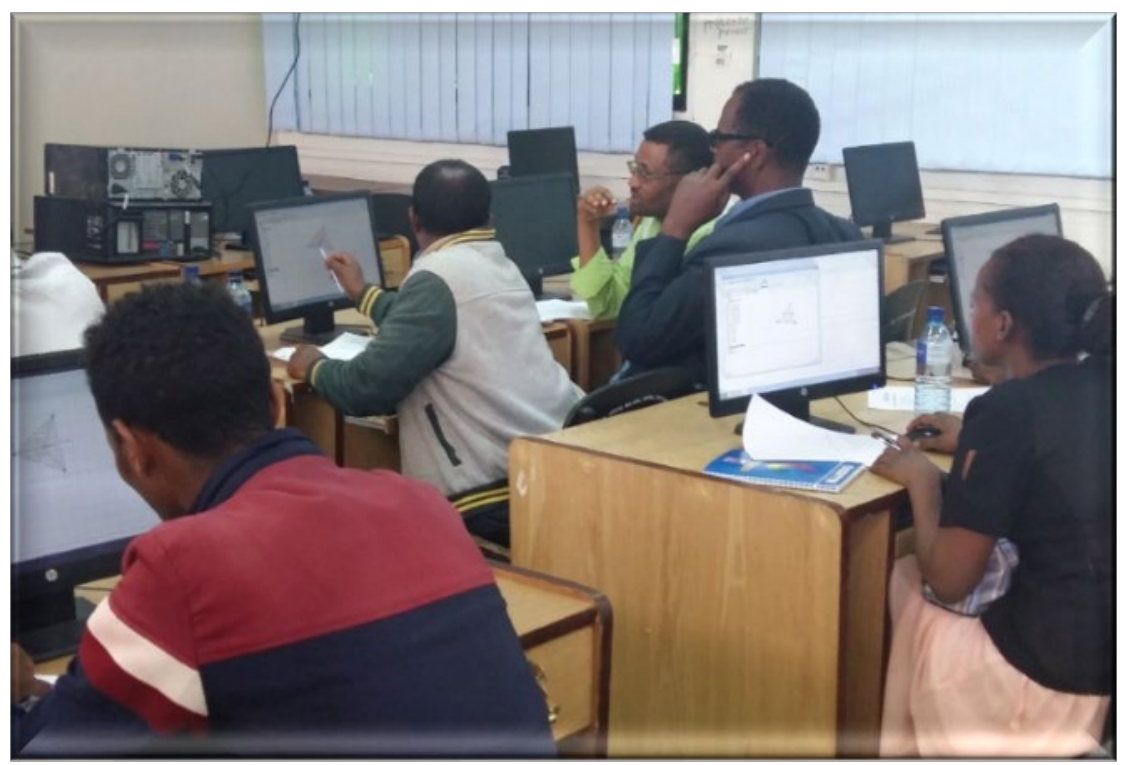

Figure 8. School teachers participating in the training by GeoGebra

(Bulut et al., 2016), and on transformation geometry (Seloraji \& Eu, 2017; Xistouri \& Pitta-pantazi, 2013) improved students' academic result. Interestingly, students also become more responsible for their own learning and actively engaged more often in the class (Dikovic, 2009b; Pierce \& Stacey, 2011).

In the sections that follow, we illustrate the case on the relevance of GeoGebra in the teaching and learning of mathematics contents in view of teachers and students. Based on our years of experience and discussion with teachers and students, we also present the challenges and limitations of GeoGebra.

Reflection of trainees. To see the views of teachers on the use of GeoGebra in school mathematics, we have conducted 24 hours training for Eighteen Mathematics teachers that were selected randomly from six schools in the city of Bahir Dar, Ethiopia. We demonstrated selected topics of mathematics using the software. Sessions were engaging supported with worksheets. Latter we conduct a panel discussion to allow trainees to reflect their views about GeoGebra and its implication in school mathematics.

Our observation of sessions and trainees' reflection asserts that GeoGebra is the right tool to support Math education if used wisely. Some of the thoughts of trainees on the use of GeoGebra is presented as follows.

- "It would have been nice if I know GeoGebra before. The dynamic nature of the software makes concepts clear-it is now, I understood the concept of approximating derivative with slopes of the tangent line"

- "The importance of the software is unquestionable- the problem is we don't have resources/computers in the school, how are we going to disseminate the knowledge we got here for our colleagues and students?"

- "Such training should also be given for other teachers who don't get the opportunities- it is really helpful".

We had also explored MathCamp program participant students' reflections about GeoGebra. Among many others, we observed that most students were interested in and actively engaged in GeoGebra sessions. Our assessment of the sessions is also supported by students' reflection which is presented as follows.

- "GeoGebra enables me to see what I haven't seen before in class. I would like to take the software to my home and practice it daily. I got them very useful and interesting."

- "Learning with GeoGebra improves my interest in learning mathematics and I got a unique and unforgettable experience."

- "Why not we learn mathematics with GeoGebra in our schools? It is more understandable to visualize graphs of functions and mathematics in general."

- "Now I understood effects of reflection, translation and rotation which I didn't before."

We also noticed that few students were passing to results missing arguments behind it. Mainly, students from rural areas and teachers who were not previously familiar with computers also faced difficulties in actively using the functionalities of the software.

GeoGebra to assimilate different learning styles. According to Liu et al. (2011), GeoGebra improves student interest and allows different learning styles to flourish. Students prefer learning with GeoGebra than with traditional approaches (Aktumen \& Bulut, 2013; Arbain \& Shukor, 2015; Gülseçen, 2012). GeoGebra is a suitable 
tool to implement both student centered and teacher centered approach. More importantly, students' involvement in lessons, their collaboration, and their reasoning skills are improved while using GeoGebra (Granberg \& Olsson, 2015; Hähkiöniemi, 2013; Takači et al., 2015). A methodological framework signifying GeoGebra's role as an amplifier and an organizer is presented by (Sherman, 2014). Students may use what the teacher constructed before the class, saving instruction time or the teacher may forward ideas so that students can investigate questions, deduce patterns and prove conjectures by their own.

Demonstration of the dynamic nature of calculus on a blackboard has been one of the difficult and challenging activity to many mathematics teachers for years. A decade ago, Hohenwarter et al. (2008) established a way to use the dynamic nature of GeoGebra for clarifying concepts of derivatives; Taylor polynomials, Riemann integrals. On the assessment side, when the class size is reasonable, teachers can deliver immediate feedback to students. Students could also validate their work by themselves (Mousoulides, 2011). In fact, to facilitate the assessment, the teacher may prepare guiding practice sheets or applets accompanied by triggering questions designed in line with the objectives of the lessons.

\section{Challenges and Limitations of Integrating GeoGebra in Mathematics Lessons} points.

In spite of all its benefits discussed above, users and developers of GeoGebra need to be aware of the following

Challenges to integrating GeoGebra. Among many others, the accessibility of resources-computers, awareness of stakeholders, pedagogical knowledge to integrate GeoGebra, student class ratio, and technology fluency of users are some of the challenges to deliver effective GeoGebra integrated math education. Actually, getting the resources is neither the end goal nor a guarantee for securing the objectives of lessons. They are rather vehicles to the destination. It is reasonable to say no technology satisfies all the needs of its users. It requires smart use of it. The same is true for GeoGebra. GeoGebra supplemented lessons requires belief of its users, a proper plan as well as the careful implementation of sessions. While delivering GeoGebra integrated lessons, care must be given in deciding the role of the teacher, the choice of the lesson, and the design of the activities. As one can't fit for all, the choice of appropriate topics and preparation of corresponding teaching materials is on teachers' hand. In addition, before implementing a GeoGebra integrated lesson, teachers should make sure...

- the technological fluency of their students,

- the support GeoGebra might bring to instructional goals, and

- the need to secure a backup plan in the class for possible system failure or electricity interruption which is common in developing countries.

Limitations. We do value the immense contribution experts have made to the improvement and the current form of GeoGebra. However, by taking in to account the importance of the points for future upgrades, shortcomings we had experienced from GeoGebra 5.0 are presented as follows.

- Some of the commands used in the input bar are not user-friendly especially for those with no prior programming experience.

- It lacks the correct representation of graphs of discontinuous functions in an automatic way. Unless adjusted to the visible scale it is sometimes misleading to visually characterize points of discontinuity from the graphs.

- The embedded manual requires an internet connection. This restricts its use in places where there is no internet connection.

\section{CONCLUSIONS AND RECOMMENDATIONS}

The fluency of pupils in using technology is an opportunity for educational institutions to bring technology integrated lessons into practice. Thus far, GeoGebra has been found to be a crucial tool in the teaching-learning of mathematics at secondary and tertiary education. An intelligent choice of GeoGebra enhanced lessons and design of activities has the advantages to inspire students toward their learning and hence to improve their academic achievement. On the other hand, the effects of GeoGebra as an important educational resource, properly designed curricula to entertain technology integrated lessons, threats of using GeoGebra, and exploring GeoGebra's contributions in the perspective of assessing students' high-level mathematical skills are areas that demand more attention and researches. We also suggest possible improvement of GeoGebra to address diverse areas of mathematics in a friendlier way. In places where there is a shortage of computers, smartphones and tablets could be taken as a potential resource to use GeoGebra apps. Above all, the intention behind using GeoGebra in the teaching-learning of mathematics should not be to replace the traditional approach; rather, to supplement it. 


\section{REFERENCES}

Abramovich, S. (2013). Computers in Mathematics Education: An Introduction. Computers in the Schools, 30(1-2), 411. http:/ / doi.org/10.1080/07380569.2013.765305

Acuña, A. M. (2014). Polya and GeoGebra : A dynamic approach to problem solving . In A. Bilsel (Ed.), Proceedings of the Frontiers in Mathematics and Science Education Research Conference (pp. 231-235). Famagusta, North Cyprus: European Journal of Science and Mathematics Education (EJSME).

Ahmad, A., Yin, T. S., Fang, L. Y., Yen, Y. H., \& How, K. W. (2010). Incorporating multimedia as a tool into mathematics education: A case study on diploma students in multimedia university. In Procedia - Social and Behavioral Sciences, 8, 594-599. Elsevier. http:/ / doi.org/10.1016/j.sbspro.2010.12.082

Akanmu, I. A. (2016). GeoGebra: The third millennium package for mathematics instruction in Nigeria. Annals. Computer Science Series, 14, 35-43. Retrieved from http:/ / anale-informatica.tibiscus.ro/download/lucrari/ 14-1-05-Akanmu.pdf

Akcay, A. O. (2017). Instructional Technologies and Pre-Service Mathematics Teachers' Selection of Technology. Journal of Education and Practice, 8(7), 163-173. Retrieved from http:/ / files.eric.ed.gov/fulltext/EJ1137598. pdf

Akkaya, A., Tatar, E., \& Kağizmanli, T. B. (2011). Using dynamic software in teaching of the symmetry in analytic geometry: The case of GeoGebra. In G. Akçamete, H. Uzunboylu, S. Ö ülmü, A. Karahoca, C. Babado an, F. Özdaml, \& S. Kanbul (Eds.), 3rd World Conference on Educational Sciences, 15, 2540-2544. Istanbul, Turkey: Elsevier Ltd. http:/ / doi.org/10.1016/j.sbspro.2011.04.141

Aktumen, M., \& Bulut, M. (2013). Teacher candidates' opinions on real life problems designed in GeoGebra software. Anthropologist, 16(1-2), 167-176. https:/ / doi.org/10.1080/09720073.2013.11891345

Albaladejo, I. M. R., García, M. D. M., \& Codina, A. (2015). Developing Mathematical Competencies in Secondary Students by Introducing Dynamic Geometry Systems in the Classroom. TED EĞİTIM VE BILIMM, 40(177), 43-58. http://doi.org/10.15390/EB.2015.2640

Anabousy, A., Daher, W., Baya'a, N., \& Abu-Naja, M. (2014). Conceiving function transformations in different representations: Middle school students working with technology. International Electronic Journal of Mathematics Education, 9(1-2), 99-114.

Arbain, N., \& Shukor, N. A. (2015). The Effects of GeoGebra on Students Achievement. Procedia - Social and Behavioral Sciences, 172, 208-214. http:/ / doi.org/10.1016/j.sbspro.2015.01.356

Bhagat, K. K., \& Chang, C. Y. (2015). Incorporating GeoGebra into Geometry learning-A lesson from India. EURASIA Journal of Mathematics, Science \& Technology Education, 12(8), 77-86. http://doi.org/10.12973/ eurasia.2015.1307a

Bray, A., \& Tangney, B. (2017). Technology usage in mathematics education research - A systematic review of recent trends. Computers and Education, 114, 255-273. http:/ / doi.org/10.1016/j.compedu.2017.07.004

Breda, A. M. D. A., \& Santos, J. M. D. S. Dos. (2016). Complex functions with GeoGebra. Teaching Mathematics and Its Applications, 35(2), 102-110. http:/ / doi.org/10.1093/teamat/hrw010

Bulut, M., Akçakın, H. Ü., Kaya, G., \& Akçakın, V. (2016). The effects of geogebra on third grade primary students' academic achievement in fractions. Mathematics Education, 11(2), 327-335. http://doi.org/10.12973/iser. 2016.2109a

Caligaris, M. G., Schivo, M. E., \& Romiti, M. R. (2015). Calculus GeoGebra, an Interesting Partnership. Procedia Social and Behavioral Sciences, 174, 1183-1188. http:/ / doi.org/10.1016/j.sbspro.2015.01.735

Chan, Y. (2013). GeoGebra as a tool to explore, conjecture, verify, justify, and prove: The case of a circle. North American GeoGebra Journal, 2(1), 14-18. http:/ / doi.org/S0272638601627586 [pii]

Dikovic, L. (2009a). Applications GeoGebra into teaching some topics of mathematics at the college level. Computer Science and Information Systems, 6(2), 191-203. http:/ / doi.org/10.2298/CSIS0902191D

Dikovic, L. (2009b). Implementing Dynamic Mathematics Resources with GeoGebra at the College Level. International Journal of Emerging Technologies in Learning (IJET), 4(3), 51-54. http://doi.org/10.3991/ijet.v4i3.784

Dvir, A., \& Tabach, M. (2017). Learning extrema problems using a non-differential approach in a digital dynamic environment: the case of high-track yet low-achievers. ZDM - Mathematics Education, 49(5), 785-798. http://doi.org/10.1007/s11858-017-0862-8

Emaikwu, O. S., Iji, C. O., \& Abari, M. T. (2015). Effect of Geogebra on Senior Secondary School Students' Interest and Achievement in Statistics in Makurdi Local Government Area of Benue State, Nigeria. IOSR Journal of Mathematics Ver, 11(3), 2278-5728. http:/ / doi.org/10.9790/5728-11341421 
Escuder, A., \& Furner, J. M. (2011). The Impact of GeoGebra in Math Teacher's Professional Development. In International Conference on Technologies in Collegiate Mathematics (pp. 76-84). Denver, Colorado, USA: Pearson.

Garber, K., \& Picking, D. (2010). Technology tips: Exploring algebra and geometry concepts with GeoGebra. Mathematics Teacher, 104(3), 226-229.

Granberg, C., \& Olsson, J. (2015). ICT-supported problem solving and collaborative creative reasoning: Exploring linear functions using dynamic mathematics software. Journal of Mathematical Behavior, 37, 48-62. http:/ / doi.org/10.1016/j.jmathb.2014.11.001

Gülseçen, P. S. (2012). Can Geogebra Make Easier the Understanding of Cartesian Co-Ordinates? A Quantitative Study in Turkey. International Journal on New Trends in Education and Their Implications, 3(4), 19-29.

Hähkiöniemi, M. (2013). Teacher's reflections on experimenting with technology-enriched inquiry-based mathematics teaching with a preplanned teaching unit. Journal of Mathematical Behavior, 32(3), 295-308. http:/ / doi.org/10.1016/j.jmathb.2013.03.007

Hohenwarter, M., Hohenwarter, J., Kreis, Y., \& Lavicza, Z. (2008). Teaching and learning calculus with free dynamic mathematics software GeoGebra. In 11th International Congress on Mathematical Education (pp. 1-9). Monterrey, Mexico.

José, M., Meneu, B., Arcila, M. M., \& Mora, E. J. (2017). A Teaching Proposal for the Study of Eigenvectors and Eigenvalues. Journal of Technology and Science Education JOTSE, 7(1), 2017-7. http://doi.org/10.3926/jotse. 260

Kaput, J., Noss, R., \& Hoyles, C. (2008). Developing New Notations for a Learnable Mathematics in the Computational Era. In L. English (Ed.), Handbook of International Research in Mathematics Education (2nd ed., pp. 693-716). New York, London: Routledge. http:// doi.org/10.1.1.135.8172

Khalil, M., Farooq, R. A., Çakıroğlu, E., Khalil, U., \& Khan, D. M. (2018). The Development of Mathematical Achievement in Analytic Geometry of Grade-12 Students through GeoGebra Activities. Eurasia Journal of Mathematics, Science and Technology Education, 14(4), 1453-1463. http:/ / doi.org/10.29333/ ejmste/83681

Kovács, Z., \& Sólyom-Gecse, C. (2016). GeoGebra Tools with Proof Capabilities, (March), 22. Retrieved from http://arxiv.org/abs/1603.01228

Laigo, G. R., Bhatti, A. H., P., L. K., \& GebreYohannes, H. M. (2016). Revisiting Geometric Construction using Geogebra. Electronic Journal of Mathematics \& Technology, 10(1), 35-43.

Lawless, K. A., \& Pellegrino, J. W. (2007). Professional Development in Integrating Technology Into Teaching and Learning: Knowns, Unknowns, and Ways to Pursue Better Questions and Answers. Review of Educational Research, 77(4), 575-614. http:/ / doi.org/10.3102/0034654307309921

Lepmann, T., \& Albre, J. (2008). Some possibilities of teaching geometry with GeoGebra. (Programmi GeoGebra kasutamisvõimalusi geomeetria õpetamisel.). Koolimatemaatika, (35), 52-57.

Little, C. (2008). Interactive geometry in the classroom: old barriers and new opportunities. Proceedings of the British Society for Research into Learning Mathematics, 28(2), 49-54. Retrieved from http:/ /www.bsrlm.org.uk/IPs/ ip28-2/BSRLM-IP-28-2-09.pdf

Little, C. (2011). Approaches to Calculus Using GeoGebra. In L. Bu \& R. Schoen (Eds.), Model-Centered Learning: Pathways to Mathematical Understanding Using GeoGebra (pp. 191-204). Rotterdam: SensePublishers. http://doi.org/10.1007/978-94-6091-618-2_14

Liu, C. S., Lai, A. F., \& Chen, Y. (2011). Apply GeoGebra to develop digital materials of angle concept for the fourth grade students. In 2011 International Conference on Electrical and Control Engineering, ICECE 2011 - Proceedings (pp. 6357-6361). Yichang, China: IEEE. http:// doi.org/10.1109/ICECENG.2011.6056805

Ljajko, E., Mihajlović, M., \& Pavličić, Z. (2010). The hyperbola and Geogebra in high-school instruction. Teaching Mathematics and Computer Science, 8(2), 277-285. https:/ / doi.org/10.5485/TMCS.2010.0265

Mainali, B., \& Key, M. (2012). Using Dynamic Geometry Software GeoGebra in Developing Countries: A Case Study of Impressions of Mathematics Teachers in Nepal. International Journal for Mathematics Teaching and Learning, 1-16. Retrieved from http:/ / www.cimt.plymouth.ac.uk/Journal/mainali.pdf

Majerek, D. (2014). Applications of GeoGebra for Teaching Mathematics. Advances in Science and Technology Research Journal, 8(24), 51-54. http:/ /doi.org/10.12913/22998624/567

Martín-Caraballo, A. M., \& Tenorio-Villalón, Á. F. (2015). Teaching numerical methods for non-linear equations with Geogebra-based activities. International Electronic Journal of Mathematics Education, 10(2), 53-65. http://doi.org/10.12973/mathedu.2015.104a 
Moeller, B., \& Reitzes, T. (2011). Integrating Technology with Student-Centered Learning. A Report to the Nellie Mae Education Foundation. Education Development Center, Inc. Quincy MA. Retrieved from http://eric.ed.gov/?id $=\mathrm{ED} 521868$

Molnár, P. (2016). Solving a Linear Optimization Word Problems by Using GeoGebra. International Journal of Information and Communication Technologies in Education, 5(2), 16-28. http:/ / doi.org/10.1515/ijicte-2016-0006

Mousoulides, N. G. (2011). GeoGebra as a Conceptual Tool for Modeling Real World Problems. In L. Bu \& R. Schoen (Eds.), Model-Centered Learning: Pathways to mathematical understanding using GeoGebra (pp. 105-118). Rotterdam: SensePublishers. http:/ / doi.org/10.1007/978-94-6091-618-2_8

Muzdalipah, I., \& Yulianto, E. (2015). The Aplication of Geogebra in Mathematical Problem Solving and Problem Posing of Prospective Teacher. Jurnal Siliwangi, 1(1), 63-74.

Navetta, A. (2016). Visualizing Functions of Complex Numbers Using GeoGebra. North American GeoGebra Journal, $5(2), 17-25$.

Pereira, L. R., Maria, J., \& Jardim, D. F. (2017). Practices for Geometry Teaching Using Geogebra. In Pixel (Ed.), International Conference New Perspectives in Science Education (6th ed.). Libreria Universitaria.

Pierce, R., \& Stacey, K. (2011). Using Dynamic Geometry to Bring the Real World Into the Classroom. In L. Bu \& R. Schoen (Eds.), Model-Centered Learning: Pathways to Mathematical Understanding Using GeoGebra (pp. 41-55). Rotterdam: SensePublishers. http:/ / doi.org/10.1007/978-94-6091-618-2_4

Pjanic, K., \& Liđan, E. (2015). One Usage of Geogebra in Enhancing Pre-service Mathematics Teachers' Content Knowledge. Turkish Journal of Computer and Mathematics Education (TURCOMAT), 6(1), 18. http:/ / doi.org/10.16949/turcomat.78085

Radović, S. (2013). Teaching Materials “Surface Area of Geometric Figures," Created Using the Software Package. European Journal of Contemporary Education, (4). https:/ / doi.org/10.13187/ ejced.2013.4.72

Rahman, M. H. A., \& Puteh, M. (2017). Learning trigonometry using GeoGebra learning module: Are under achieve pupils motivated? AIP Conference Proceedings, 1750, 39-42. http:/ / doi.org/10.1063/1.4954586

Saha, R. A., Ayub, A. F. M., \& Tarmizi, R. A. (2010). The Effects of GeoGebra on Mathematics Achievement: Enlightening Coordinate Geometry Learning. Procedia - Social and Behavioral Sciences, 8, 686-693. http:/ / doi.org/10.1016/j.sbspro.2010.12.095

Seloraji, P., \& Eu, L. K. (2017). Students' Performance in Geometrical Reflection Using GeoGebra. Malaysian Online Journal of Educational Technology, 5(1), 65-77. Retrieved from http:/ / search.ebscohost.com/login.aspx?direct $=$ true $\& \mathrm{db}=$ eric $\& A N=E J 1125133 \&$ site $=$ ehost-live

Sherman, M. (2014). The Role of Technology in Supporting Students' Mathematical Thinking: Extending the Metaphors of Amplifier and Reorganizer. Contemporary Issues in Technology and Teacher Education, 14(3), 220246.

Stando, J., Gwozdz-Lukawska, G., \& Guncaga, J. (2012). From the Pythagorean Theorem to the definition of the derivative function. In 2012 International Conference on E-Learning and E-Technologies in Education (ICEEE) (pp. 54-58). Lodz, Poland: IEEE. http:/ / doi.org/10.1109/ICeLeTE.2012.6333421

Takači, D., Stankov, G., \& Milanovic, I. (2015). Efficiency of learning environment using GeoGebra when calculus contents are learned in collaborative groups. Computers and Education, 82, 421-431. http:// doi.org/10.1016/j.compedu.2014.12.002

Velichova, D. (2011). Interactive Maths with GeoGebra. International Journal of Emerging Technologies in Learning (IJET), 6(S1), 31-35. http:/ / doi.org/10.3991/ijet.v6iS1.1620

Xistouri, X., \& Pitta-pantazi, D. (2013). Using GeoGebra to develop primary school students' understanding of reflection. North American GeoGebra Journal, 2(1), 19-23.

Zengin, Y., Furkan, H., \& Kutluca, T. (2012). The effect of dynamic mathematics software geogebra on student achievement in teaching of trigonometry. In Procedia - Social and Behavioral Sciences, 31, 183-187. http:/ / doi.org/10.1016/j.sbspro.2011.12.038

\section{http://www.ejmste.com}

